\title{
SUBSTRATOS ALTERNATIVOS E TRATAMENTOS PRÉ-GERMINATIVOS NA GERMINAÇÃO in vitro DE SEMENTES DE Pinus taeda L. ${ }^{1}$
}

\author{
Diego Pascoal Golle ${ }^{2}$, Lia Rejane Silveira Reiniger ${ }^{3}$, Aline Ritter Curti ${ }^{4}$, Joana Graciela Hanauer ${ }^{5}$ e \\ Daniel Arthur Gaklik Waldow ${ }^{6}$
}

\begin{abstract}
RESUMO - Os objetivos deste trabalho foram desenvolver protocolos para a obtenção de plântulas in vitro de P. taeda, avaliar o uso de substratos alternativos e analisar o efeito de tratamentos pré-germinativos na otimização da germinação. Foram testados tratamentos de desinfestação à base de etanol e hipoclorito de sódio $(\mathrm{NaOCl})$, a influência do fotoperíodo, de tratamentos pré-germinativos e a possibilidade de uso de substratos alternativos (amido de milho, papel-filtro, algodão hidrófilo, vermicultita, ágar-água e adição de carvão ativado ao meio nutritivo) na germinação. Foram avaliadas a germinação in vitro e a contaminação fúngica e bacteriana. O melhor tratamento para a desinfestação das sementes foi etanol $70 \%$ por $30 \mathrm{~s}$, seguido de imersão em hipoclorito de sódio a $3 \%$ por $5 \mathrm{~min}$, no entanto apresentou efeito tóxico. Os substratos alternativos conferem condições físicas adequadas à cultura de tecidos, mas não favorecem a germinação. Contudo, o uso de algodão hidrófilo associado à embebição das sementes por 72 h, na ausência de desinfestação, otimiza a germinação e possibilita a obtenção de plântulas in vitro com baixa contaminação.
\end{abstract}

Palavras-chave: Desinfestação de sementes, Cultura de tecidos e Contaminação.

\section{ALTERNATIVE SUBSTRATES AND PRE-GERMINATIVE TREATMENTS IN THE in vitro GERMINATION OF Pinus taeda L. SEEDS}

\begin{abstract}
The aims of this paper were to develop protocols to obtain in vitro seedlings of $\mathrm{P}$. taeda, evaluate the use of alternative substrates as well as analyze the effect of pre-germinative treatments for optimizing germination. Disinfestation treatments using sodium hypochlorite, influence of photoperiod and pre-germinative treatments, and the possibility of using alternative substrates (maize starch, filter paper, hydrophile cotton, vermiculite, agar-water and addition of activated charcoal into the nutritive medium) were tested for germination. In vitro germination, fungal and bacterial contamination were evaluated. The best seed disinfestation treatment was ethanol at $70 \%$ for 30 seconds + sodium hypochlorite at $3 \%$ for 5 minutes. However, it caused a toxic effect. Alternative substrates provide adequate physical conditions to tissue culture, but do not favor germination. Nevertheless, the use of hydrophile cotton associated with seed soaking for 72 hours, without disinfestation, enhances germination and provides in vitro seedlings with low contamination.
\end{abstract}

Keywords: Seed desinfestation, Tissue culture and Alternative substrates.

\section{INTRODUÇÃO}

Segundo Tuoto (2003), há uma crise na demanda de madeira no Brasil que tende a agravar-se. Face ao exposto, o desenvolvimento de pesquisas tecnológicas visando aumentar a utilização de madeiras de reflorestamento em relação às nativas é de suma importância (WATAI, 1990). Nesse sentido, a produção de mudas de espécies lenhosas de rápido crescimento e alta qualidade para a obtenção de produtos florestais é essencial nos dias atuais.

\footnotetext{
${ }^{1}$ Recebido em 16.01.2008 e aceito para publicação em 14.10.2009.

${ }^{2}$ Universidade Federal de Santa Maria, Departamento de Solos - Santa Maria, RS - Brasil .E-mail: <diegolle@yahoo.com.br>.

${ }^{3}$ Universidade Federal de Santa Maria, Centro de Ciências Rurais, Departamento de Fitotecnia - Santa Maria, RS - Brasil. E-mail: <liarejanesilveirareiniger@yahoo.com.br>.

${ }^{4}$ Programa de Pós-graduação em Engenharia Florestal da Universidade Federal de Santa Maria - Santa Maria, RS - Brasil. E-mail: <alinerittercurti@yahoo.com.br>.

${ }^{5}$ Programa de Pós-graduação em Agronomia da Universidade Federal de Santa Maria - Santa Maria, RS - Brasil .E-mail: <joana2hanauer@yahoo.com.br>.

${ }^{6}$ Programa de Pós-graduação em Fitotecnia da Universidade Federal do Rio Grande do Sul - Porto Alegre, RS - Brasil. Email: <daniwaldow@bol.com.br>.
} 
As maiores unidades produtoras de madeira serrada do país se encontram nas Regiões Sul e Sudeste, e entre as espécies madeireiras que se destacam estão aquelas pertencentes ao gênero Pinus. Essas unidades utilizam madeira do gênero em questão como matéria-prima, porém, o baixo grau tecnológico e a mão de obra pouco qualificada tornam a atividade com baixa competitividade (ABIMCI, 2001). Além disso, Pinus taeda L. é de muita importância em programas de florestamento, reflorestamento e demais atividades ligadas ao setor madeireiro. Essa preferência pela espécie se deve, principalmente, ao fato de possuir crescimento rápido, atingindo grandes incrementos anuais em altura (SELLE et al., 1994). P. taeda costuma ser propagado por meio de sementes, já que estas são produzidas em grande escala. Sua madeira é usada para fabricação de barcos, postes e dormentes, na construção civil, serraria, laminação, produção de papel, entre outras. No Sul do Brasil, costuma ser cultivada nas regiões mais altas do planalto catarinense e na serra gaúcha (LORENZI et al., 2004), e, em algumas regiões, os plantios de Pinus permanecem como um dos poucos recursos financeiros viáveis para a população (BACKES e IRGANG, 2004).

Segundo o Instituto de Pesquisas e Estudos Florestais (IPEF, 2002) existe, no setor florestal, a necessidade do desenvolvimento de técnicas ligadas à produção de clones melhorados para disponibilização no mercado. Atualmente, as sementes coletadas passam por rigoroso controle de qualidade, que se inicia na escolha das árvores que servirão como matrizes na coleta de sementes. Testes de geminação e de sanidade são necessários para garantir a qualidade deste tipo de propágulo (FERRARI, 2003).

O aumento populacional e a excessiva demanda por produtos oriundos das espécies vegetais requerem incrementos na produtividade, os quais podem ser obtidos por meio da biotecnologia (WATANABE e RAMAN, 1997). A cultura de tecidos é o processo em que fragmentos de tecidos vegetais vivos denominados de explantes - são retirados e cultivados em meio nutritivo definido (SERAFINI et al., 2001), permitindo a obtenção de mudas micropropagadas. As gimnospermas estão entre as primeiras espécies que foram cultivadas in vitro, entretanto, o grande avanço nas pesquisas com angiospermas diminuiu o número de trabalhos com gimnospermas (PARANJOTHY, 1990). Além disso, a propagação, germinação e enraizamento in vitro de espécies lenhosas são processos mais complicados, somando-se a isso os grandes índices de oxidação, oriunda síntese de

R. Árvore, Viçosa-MG, v.34, n.1, p.39-48, 2010 compostos fenólicos precursores da síntese de lignina, os quais podem, até mesmo, ocasionar a morte dos explantes (GEORGE e SHERRINGTON, 1984; PARANHOTY, 1990; TEIXEIRA, 2004).

Diversos trabalhos têm sido realizados com o cultivo in vitro de espécies do gênero Pinus, como: P. patula (McKELLAR et al., 1994), P. elliottii (BURNS et al., 1991), P. heldreichii (STOJIEIÉ et al., 1999) e P. taeda (LI e HUANG, 1996; PULLMAN et al., 2003). Tais pesquisas são, em seu maior número, ligadas à embriogênese somática, processo mais difícil e trabalhoso, tanto pelos explantes necessários (os quais geralmente necessitam de coleta em estágio imaturo) quanto pela execução laboratorial. Em contrapartida, a germinação in vitro das sementes oferece maior facilidade nos trabalhos, possibilidade de multiplicação por organogênese direta, juvenilidade e maior variabilidade num mesmo lote, possibilitando melhoramento e seleção.

Desta forma, os objetivos deste trabalho foram desenvolver protocolos para a obtenção de plantas germinadas in vitro de $P$. taeda, avaliar o uso de substratos alternativos e analisar o efeito de tratamentos pré-germinativos na otimização da germinação.

\section{MATERIAL E MÉTODOS}

Os experimentos relatados na sequência foram desenvolvidos no Laboratório de Cultura de Tecidos Vegetais, pertencente ao Núcleo de Biotecnologia e Melhoramento do Departamento de Fitotecnia, Centro de Ciências Rurais, da Universidade Federal de Santa Maria, Santa Maria, Rio Grande do Sul, Brasil. As sementes utilizadas pertenciam ao lote de sementes Celucat 8203 e foram cedidas pela empresa Klabin, juntamente com outros dois lotes. Esse lote foi selecionado por meio de suas qualidades sanitárias e fisiológicas, conforme descrito em Golle (2007). As sementes apresentavam teor de umidade de $11,86 \%$ e foram acondicionadas em câmara fria com temperatura controlada de $10^{\circ} \mathrm{C}$ e umidade relativa do ar de $45 \%$ durante o período de execução dos experimentos (120 dias).

Todos os experimentos foram conduzidos em sala de cultivo com temperatura controlada de $25^{\circ} \mathrm{C} \pm 3$, fotoperíodo de $16 \mathrm{~h}$, com intensidade luminosa de 20

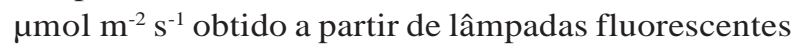
brancas frias. No experimento em que houve ausência de fotoperíodo em alguns tratamentos, as condições foram as mesmas, à exceção da luminosidade. 
Os dados foram transformados pela função $\sqrt{x+0,5}$ e submetidos à análise de variância com o auxílio do programa ESTAT (Unesp-Jaboticabal). Quando o valor de " $F$ " foi significativo, dados oriundos de tratamentos qualitativos tiveram suas médias comparadas por meio do teste de Tukey a $5 \%$ de probabilidade de erro, enquanto que, dados de tratamentos quantitativos, foram submetidos a análise de regressão polinomial". Os dados foram transformados após a sua normalidade ter sido testada pelo teste de Kolmogorov-Smirnov e a homogeneidade das variâncias pelo teste de Bartlett; no entanto, para exposição nos gráficos e tabelas foram utilizados os originais.

\subsection{Desinfestação e Germinação Asséptica das Sementes}

Este trabalho foi conduzido em delineamento inteiramente casualizado, em esquema bifatorial $3 \times 2$, com 21 repetições, sendo cada uma composta por um frasco com capacidade para $150 \mathrm{ml}$, contendo $30 \mathrm{ml} \mathrm{de}$ meio, três sementes e vedado com papel-alumínio. Os níveis do fator " $\mathrm{A}$ " consistiram de diferentes combinações entre tempos e concentrações de hipoclorito de sódio ( $\mathrm{NaOCl})$, cujo objetivo foi utilizar concentrações elevadas em tempos restritos e concentrações reduzidas em tempo maior, constituindo-se esses níveis em tratamentos qualitativos. Os níveis foram: 1) solução de $\mathrm{NaOCl} 2 \%$ durante $10 \mathrm{~min}$; 2) solução de $\mathrm{NaOCl} 3 \%$ durante $5 \mathrm{~min}$; e 3) solução de $\mathrm{NaOCl} 4 \%$ durante 3 min. As concentrações foram obtidas a partir de diluições de uma solução de $\mathrm{NaOCl} 10 \%$. O fator "B" consistiu da presença de fotoperíodo durante o período experimental ou somente a partir dos sete primeiros dias de instalação.

Precedendo os tratamentos, todas as sementes permaneceram por $30 \mathrm{~s}$ em solução de etanol $70 \% \mathrm{e}$, posteriormente, foram lavadas em água destilada esterilizada. Após a aplicação dos tratamentos, as sementes foram submetidas a três enxágues sucessivos com água estéril. A inoculação das sementes ocorreu em meio ágar-água composto de 0,07\% de ágar e água. Todos os procedimentos ocorreram em câmara de fluxo laminar. O meio de cultivo foi previamente autoclavado a $121^{\circ} \mathrm{C}$ e 1 atm de pressão durante $45 \mathrm{~min}$.

As variáveis analisadas foram: contaminação fúngica, contaminação bacteriana, germinação e oxidação fenólica. As avaliações foram realizadas durante observações no período de quatro semanas e os dados obtidos a partir do somatório do total de observações aos 28 dias.

\subsection{Substratos Alternativos: papel-filtro, amido de milho + água, e amido de milho + ágar + água}

Este trabalho foi conduzido em delineamento inteiramente casualizado com três tratamentos e 23 repetições. Cada repetição foi composta por um frasco com capacidade para $150 \mathrm{ml}$ contendo o substrato referente ao tratamento em questão e três sementes. As sementes foram desinfestadas por $30 \mathrm{~s}$ em solução de álcool 70\%, lavadas em água destilada estéril, agitadas em solução de $\mathrm{NaOCl} 3 \%$ acrescida de duas gotas de detergente comercial por 5 min e inoculadas assepticamente em câmara de fluxo laminar.

Os tratamentos consistiram de: 1) três folhas de papel-filtro umedecidas com água estéril até atingir três vezes o peso do papel; 2) meio de cultura contendo água e amido de milho, como solidificante alternativo, na proporção de $100 \mathrm{~g} \mathrm{~L}^{-1}$; e 3) meio de cultura composto por água, $1,5 \mathrm{~g} \mathrm{~L}^{-1}$ de ágar e $75 \mathrm{~g} \mathrm{~L}^{-1}$ de amido de milho. Os frascos com substrato foram autoclavados por $20 \mathrm{~min}$ a $121^{\circ} \mathrm{C}$ e $1 \mathrm{~atm}$ de pressão.Foram avaliadas, aos 28 dias, as variáveis: germinação, contaminação fúngica, contaminação bacteriana e oxidação fenólica.

\subsection{Substratos Alternativos: meio MS + vermiculita, e meio MS + ágar + carvão ativado}

Neste trabalho, os tratamentos utilizados foram: 1) meio de cultura MS (MURASHIGE e SKOOG, 1962) líquido sobre $3 \mathrm{~g}$ de vermiculita (rocha expandida) de granulometria 2; e 2) meio MS solidificado com $0,07 \%$ de ágar e acrescido de $1 \mathrm{~g} \mathrm{~L}^{-1}$ de carvão ativado. O meio de cultura $(30 \mathrm{~mL} ; \mathrm{pH} 5,8)$ foi distribuído em frascos com capacidade para $150 \mathrm{~mL}$, os quais foram vedados com papel-alumínio. Em seguida, o material foi autoclavado a uma temperatura de $121^{\circ} \mathrm{C}$ e $1 \mathrm{~atm}$ de pressão durante $20 \mathrm{~min}$.

As sementes, após a desinfestação superficial (citada no experimento anterior), foram inoculadas em número de 3, nos frascos. Esse procedimento ocorreu em câmara de fluxo laminar. O experimento foi conduzido em delineamento inteiramente casualizado, com 20 repetições.

As avaliações foram realizadas aos 28 dias. As variáveis observadas foram: contaminação fúngica, contaminação bacteriana, germinação e oxidação fenólica.

R. Árvore, Viçosa-MG, v.34, n.1, p.39-48, 2010 


\subsection{Tratamentos Pré-Germinativos e Substrato de Algodão Hidrófilo}

Conduziram-se dois testes separadamente, alterando alguns fatores, sendo o segundo realizado em decorrência das observações do primeiro.

No primeiro teste de tratamentos pré-germinativos e germinação em algodão hidrófilo, testou-se a embebição das sementes nos períodos de 24,48 e $72 \mathrm{~h}$, as quais foram imersas em frascos com capacidade para 150 $\mathrm{mL}$ contendo $50 \mathrm{~mL}$ de água destilada. Após a embebição, as sementes foram desinfestadas por $30 \mathrm{~s}$ em solução de etanol 70\%, lavagem em água destilada e imersão por 5 min em solução de $\mathrm{NaOCl} 3 \%$, acrescido de duas gotas de detergente comercial, visando surfactar a tensão superficial. Em câmara de fluxo laminar, as sementes passaram por três enxágues e foram inoculadas em frascos contendo $600 \mathrm{mg}$ de algodão hidrófilo embebido em água estéril até ficar encharcado. Os frascos com meio foram autoclavados durante $20 \mathrm{~min}$ a $121^{\circ} \mathrm{C}$ e 1 atm de pressão.

O delineamento experimental foi o inteiramente casualizado com 23 repetições, sendo cada UE composta por um frasco com o substrato citado e três sementes. As observações foram realizadas aos 28 dias, levandose em consideração as variáveis: oxidação fenólica, contaminação fúngica, contaminação bacteriana e germinação.

O segundo teste, referente aos tratamentos prégerminativos e germinação das sementes em substrato de algodão hidrófilo, ocorreu em delineamento inteiramente casualizado com 20 repetições, compostas por três sementes cada. Os tratamentos foram embebições prévias das sementes nos tempos $0,24,48$ e 72 h. O processo para embebição foi realizado da mesma forma como citado anteriormente. As sementes não foram desinfestadas, visando-se a melhora observação do efeito da embebição sobre as contaminações, referentes à possível inocuidade do algodão hidrófilo e toxidez do $\mathrm{NaOCl}$ e/ou etanol.

As análises dessa etapa foram realizadas aos 7, 14 e 21 dias, levando-se em consideração as variáveis: germinação (considerando todas as sementes com emissão da radícula), emissão de cotilédones (considerando apenas sementes germinadas que haviam exposto os cotilédones e possuíam tamanho igual ou superior a $3 \mathrm{~cm}$ ), contaminações fúngica e bacteriana.

R. Árvore, Viçosa-MG, v.34, n.1, p.39-48, 2010

\section{RESULTADOS}

\subsection{Desinfestação e Germinação Asséptica das Sementes}

A germinação, as contaminações bacteriana e fúngica e a oxidação fenólica das sementes não mostraram influência significativa da interação dos fatores ou dos seus componentes, exceto a contaminação fúngica que mostrou efeito dos componentes do fator A. A maior média de germinação foi de 3,33\% no tratamento em que as sementes permaneceram sob luz e foram desinfestadas em $\mathrm{NaOCl}$ $4 \%$ durante $3 \mathrm{~min}$. Fatores ligados ao meio físico ou químico, como toxidez causada pelo ágar, etanol, $\mathrm{NaOCl}$ ou baixa disponibilidade de água no meio de cultura, podem ter tido relação com a baixa germinação, o que levou à realização dos demais experimentos.

A desinfestação em $\mathrm{NaOCl}$ na concentração de $3 \%$ durante $5 \mathrm{~min}$ foi estatisticamente superior ao procedimento com $\mathrm{NaOCl} 2 \%$ durante $10 \mathrm{~min}$, mas não diferiu estatisticamente do tratamento com $\mathrm{NaOCl} 4 \%$ por $3 \mathrm{~min}$, o qual, por sua vez, também não diferiu do tratamento com $\mathrm{NaOCl} 2 \%$ durante $10 \mathrm{~min}$, podendo, assim, ser considerado como intermediário (Figura 1).

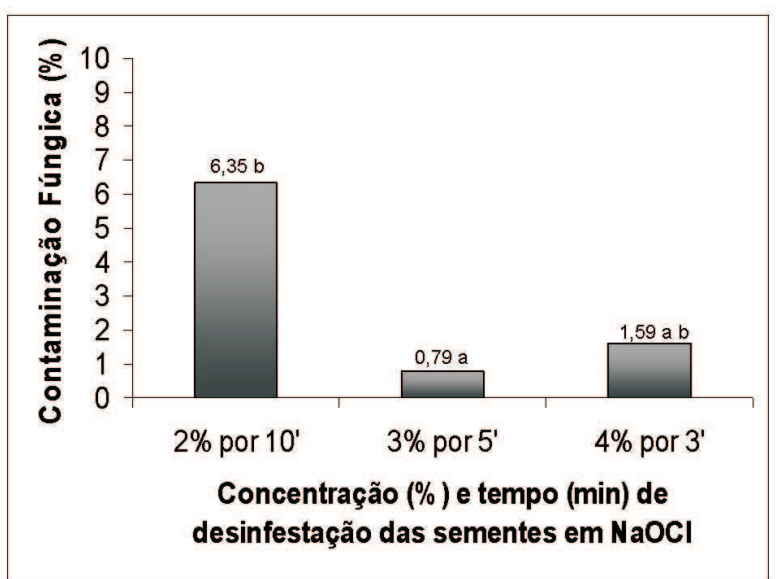

Figura 1 - Porcentagem de contaminação fúngica nos três níveis do fator A, correspondentes a diferentes tempos de desinfestação e concentrações de $\mathrm{NaOCl}$, em sementes de Pinus taeda L. Santa Maria, UFSM, 2007.

Figure 1 - Percentage of fungal contamination in the three levels of the factor A, corresponding to different times of disinfestation and concentrations of Sodium Hypochlorite (NaOCl) in Pinus taeda L. seeds. Santa Maria, UFSM, 2007. 
Tabela 1 - Porcentagem de germinação e contaminação fúngica e bacteriana de sementes de Pinus taeda L. nos meios alternativos para o cultivo in vitro: papelfiltro, água+amido de milho e água+ágar+amido de milho. Santa Maria, UFSM, 2007.

Table 1 - Percentage of germination, fungal and bacterial contamination of Pinus taeda L. seeds in alternative media for in vitro culture: Filter Paper, Water + Corn starch and Water + Agar + Corn Starch. Santa Maria, UFSM, 2007

\begin{tabular}{cccc}
\hline & \multicolumn{3}{c}{ Variáveis Observadas } \\
\cline { 2 - 4 } Substrato & Germinação & Fungos & Bactérias \\
\hline Papel-filtro & 0 a* & 0 a & 0 a \\
Água + Amido & $1,43 \mathrm{a}$ & $8,6 \mathrm{~b}$ & $1,43 \mathrm{a}$ \\
Água+Amido+Ágar & $1,43 \mathrm{a}$ & $1,43 \mathrm{a} \mathrm{b}$ & $0 \mathrm{a}$ \\
CV $(\%)$ & 4,87 & 8,99 & 3,46 \\
\hline
\end{tabular}

* Médias seguidas pela mesma letra na coluna não diferem estatisticamente, pelo teste de Tukey a 5\% de probabilidade.

\subsection{Utilização de Substratos Alternativos para a Germinação in vitro de Pinus taeda $\mathrm{L}$.}

No teste em que foram utilizados como substratos papel-filtro, meio água + amido e meio água + amido + ágar, não houve diferenças significativas para a germinação, a qual ocorreu em $1,43 \%$ das sementes inoculadas nos meios solidificados com amido e agar + amido. No meio com papel-filtro não houve germinação, provavelmente devido à ausência de água, decorrente da autoclavagem e da temperatura da sala de cultivo, considerando-se que a perda de água desse substrato em relação aos demais é visivelmente maior. Para contaminação bacteriana, também não se observaram diferenças estatísticas, sendo o meio solidificado com amido o que apresentou maior contaminação $(1,43 \%)$.

Em relação à contaminação fúngica, o tratamento papel-filtro $(0 \%)$ apresentou-se superior ao tratamento água-amido $(8,6 \%)$, porém não diferiu estatisticamente do tratamento água + amido + ágar $(1,43 \%)$. Todavia, não é possível confirmar a superioridade, considerando-se a ausência de umidade no meio papelfiltro quando comparado com os demais (Tabela 1).

O uso de vermiculita associada ao meio MS líquido e meio MS solidificado com ágar, acrescido de carvão ativado, não mostrou diferença significativa em relação à variável contaminação fúngica na análise de variância. Em contrapartida, a germinação em meio líquido contendo como suporte a vermiculita foi estatisticamente superior à germinação em meio com ágar e carvão ativado, apresentando médias de $8,33 \%$ e $0 \%$, respectivamente.
O meio líquido contendo vermiculita também foi superior ao meio MS com carvão ativado e ágar, o qual teve maior percentual de contaminação bacteriana $(0 \%$ e $33,31 \%$, respectivamente). A vermiculita não favoreceu tanto quanto o ágar o surgimento de colônias bacterianas, o que permite inferir que o ágar proporciona melhor superfície de contato para o crescimento delas, o que é desfavorável.

\subsection{Tratamentos Pré-germinativos, Germinação em Algodão Hidrófilo e Efeitos do $\mathrm{NaOCl}$ e Etanol}

Nos testes em que se utilizou o processo de desinfestação superficial nas sementes, não foram observadas diferenças estatísticas significativas para todas as variáveis, exceto contaminação fúngica, nos tempos de embebição de 24, 48 e 72 h. A contaminação fúngica apresentou comportamento quadrático, com máxima eficiência (ausência de contaminação) nas sementes que permaneceram embebidas por $48 \mathrm{~h}$, nas quais não ocorreu contaminação (Figura 2). Os dados gerados no gráfico são oriundos de transformação, por esse motivo há um ajuste da linha de tendência, a qual passa pelo valor zero. Da mesma forma, o coeficiente de determinação $\left(r^{2}\right)$ igualou-se a 1 , sendo esse fato possível quando o número de tratamentos é pequeno e a equação tem poucos graus de liberdade para desvios do modelo, em que, nesse caso, o coeficiente de determinação não faz sentido e sempre será próximo de 1, como citaram Storck et al. (2006).

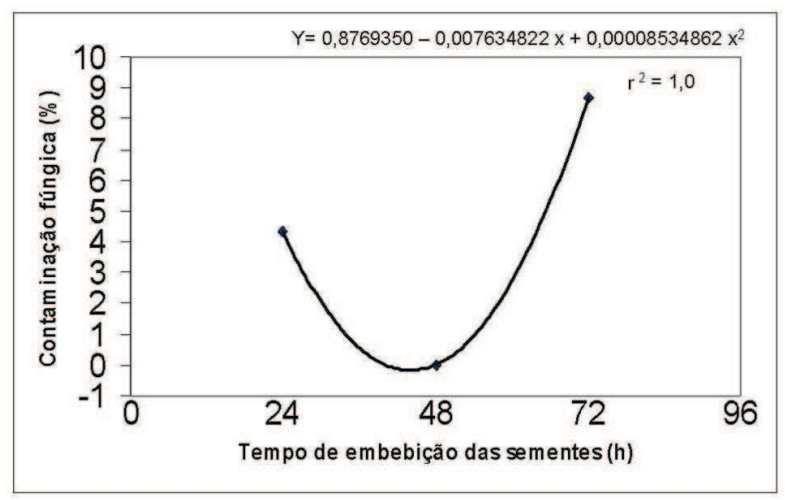

Figura 2 - Efeito dos diferentes tempos de embebição das sementes na contaminação fúngica de sementes de Pinus taeda L. desinfestadas antes da inoculação in vitro. Santa Maria, RS, UFSM, 2007.

Figure 2 - Effect of different seed soaking times in water on fungal contamination of Pinus taeda L. seeds disinfested before in vitro inoculation. Santa Maria, RS, UFSM, 2007.

R. Árvore, Viçosa-MG, v.34, n.1, p.39-48, 2010 
Observou-se, em contrapartida, que sementes que foram embebidas e inoculadas em substrato algodão hidrófilo, sem sofrer desinfestação prévia, mostraram melhores porcentagens de germinação. Esse fato permite inferir que o etanol e o $\mathrm{NaOCl}$, nas concentrações utilizadas e tempos de contato com as sementes, apresentam efeito tóxico.

Para a variável germinação aos sete dias, não houve diferenças significativas entre os tratamentos. Todavia, a maior média de germinação $(41,66 \%)$ ocorreu quando as sementes permaneceram previamente embebidas durante $72 \mathrm{~h}$ em água destilada, que pode ser considerada
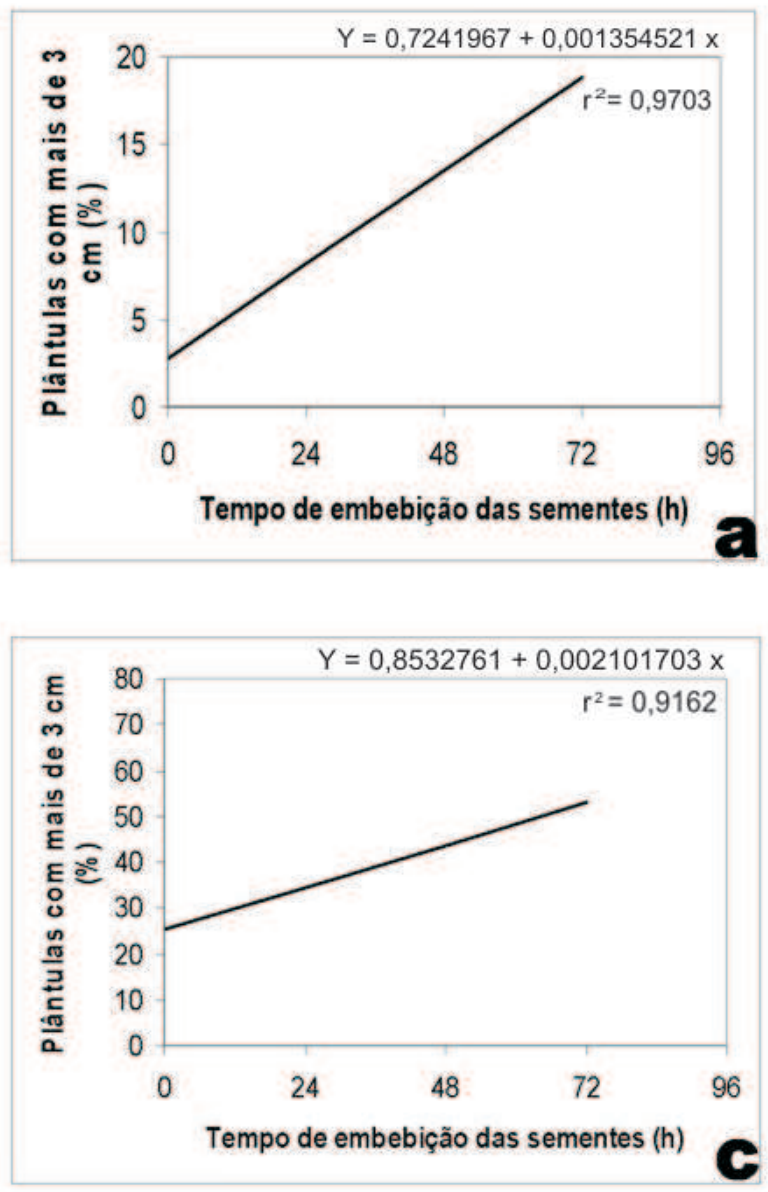

alta em comparaçâo com os resultados observados nos experimentos anteriormente citados. Em contrapartida, em sementes germinadas, e considerando aquelas que emitiram cotilédones e possuíam tamanho a partir de $3 \mathrm{~cm}$ de comprimento, observaram-se diferenças significativas aos sete dias. Essa variável apresentou comportamento linear (Figura 3), sendo a maior média de germinação encontrada nas sementes que permaneceram em embebição durante $72 \mathrm{~h}(18,33 \%)$. As sementes embebidas nos tempos de 0, 24 e $48 \mathrm{~h}$ apresentaram médias de germinação, com base nesse critério, de $1,67 \%, 9,99 \%$ e $13,33 \%$, respectivamente.
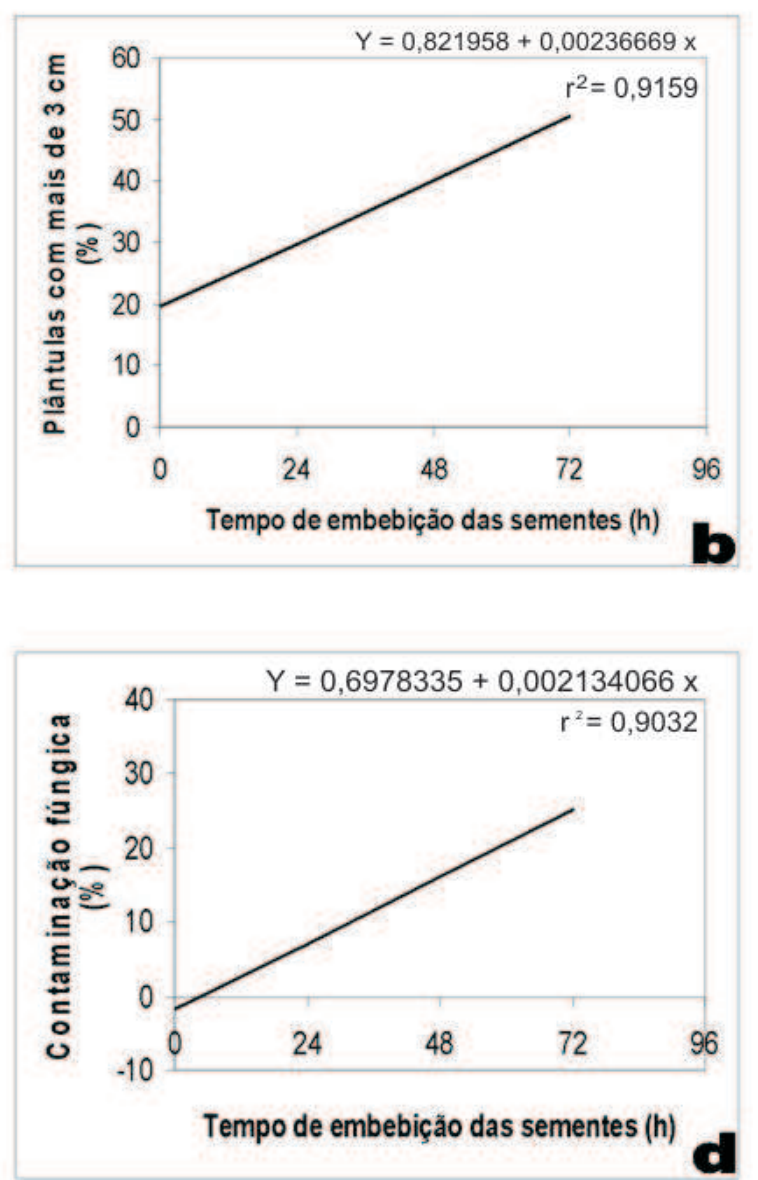

Figura 3 - Efeitos dos diferentes tempos de embebição das sementes de Pinus taeda L. em relação à emissão de cotilédones (plântulas com mais de $3 \mathrm{~cm}$ ) aos 7 (a), 14 (b) e 21 (c) dias; e porcentagem de contaminação fúngica aos 21 dias (d). Santa Maria, RS, UFSM, 2007.

Figure 3 - Effects of different seed soaking times on cotyledon formation of Pinus taeda L. (seedlings with more than 3 $\mathrm{cm})$ at $7(\mathrm{a}), 14(\mathrm{~b})$ and 21 (c) days; and percentage of fungal contamination at 21 days (d). Santa Maria, RS, UFSM, 2007.

R. Árvore, Viçosa-MG, v.34, n.1, p.39-48, 2010 
Não houve diferenças significativas nos tratamentos quanto à variável germinação aos 14 dias. Porém, esses se mostraram significativos quando, mais uma vez, se considerou a emissão de cotilédones (Figura 3). A máxima eficiência para tal tratamento ocorreu no tempo de 72 $\mathrm{h}$, apresentando a maior média de emissão de cotilédones (46,66\%). Da mesma forma, a germinação aos 21 dias só mostrou diferenças estatísticas significativas para a emissão de cotilédones, sendo mais eficiente a embebição realizada por 72 h (média de 56,33\%). Assim, foi possível determinar a emissão de cotilédones como a variável mais eficiente para avaliar a velocidade e quantidade de germinação in vitro de sementes de Pinus taeda em substrato algodão hidrófilo.

Após 21 dias, comportou-se linearmente (Figura 3) a variável contaminação fúngica. As menores taxas de contaminação foram de $0 \%$, e as maiores encontradas no tempo de embebição de $72 \mathrm{~h}$, o qual provavelmente favoreceu, com o acréscimo da umidade, a disseminação de esporos fúngicos nas sementes.

\section{DISCUSSÃO}

No teste de germinação e desinfestação asséptica, a maior média de plântulas $(3,33 \%)$ pode ser considerada muito baixa. A germinação pode ter sido afetada por fatores como toxidez causada por ágar, $\mathrm{NaOCl}$, etanol ou baixa disponibilidade de água no meio. Caldas et al. (1998) mencionaram que o ágar está entre os agentes que podem apresentar toxicidade em algumas espécies vegetais, especialmente quando possui baixo grau de pureza. Já Nogueira et al. (2004) relataram a interferência no processo de embebição necessário à germinação das sementes de Byrsonima intermedia causado pela presença de sais, carboidratos e geleificantes, alterando o potencial osmótico dos meios de cultura. Determinadas concentrações de $\mathrm{NaOCl}$ também podem afetar a germinação, como observado por Zayat e Ranal (1997) em sementes de Erechtites valerianaefolia, as quais, após a assepsia com $\mathrm{NaOCl}$, tiveram seu potencial germinativo reduzido em $24 \%$ e aumento de 2,95 dias em seu tempo de germinação.

Quanto à desinfestação, observou-se que o melhor tratamento consistiu na utilização de $\mathrm{NaOCl} 3 \%$ durante 5 min. Pérez-Bermúdez e Sommer (1987) utilizaram para desinfestação de Pinus elliottii (Engelm.) solução de $\mathrm{NaOCl}$ concentrado 3\%. Porém, esses autores também utilizaram etanol $70 \%$ durante 15 min e tratamento com ácido clorídrico diluído, excisando o embrião para os trabalhos in vitro. Li e Huang (1996) utilizaram clorox $50 \%$ durante $20 \mathrm{~min}$, também para cultivo de embriões. Em Pinus eldarica, Sen et al. (1994) utilizaram $\mathrm{NaOCl}$ na concentração de $0,8 \%$, durante $15 \mathrm{~min}$, sendo esse tratamento eficaz na assepsia das sementes para posterior excisão dos embriões. A concentração de $\mathrm{NaOCl} 6 \%$ durante 20 min foi considerado como procedimento ideal para sementes de Pinus banksiana (HARRY e THORPE, 1994). Em face do exposto, ressalta-se uma estreita relação entre as concentrações de $\mathrm{NaOCl}$ utilizadas e os tempos de contato dessas com as sementes, o que pôde ser observado na variável contaminação fúngica. O tempo e a concentração intermediários demonstraram melhor resultado quando comparados com tempos superiores com concentrações restritas e o inverso destas. Essa relação entre tempos e concentrações de $\mathrm{NaOCl}$ é muito importante para o sucesso da cultura de tecidos e pode variar muito, devendo ser adequada para propiciar a qualidade sanitária desejada sem causar a injúria ou morte dos explantes que serão utilizados (GRATTAPAGLIA e MACHADO, 1998).

A utilização de amido de milho e deste combinado com ágar mostrou-se viável na substituição total ou parcial do ágar, considerando que esses igredientes conferem suporte de boa consistência para os explantes, permanecendo assim durante o decorrer do tempo de avaliação dos experimentos. Porém, em contrapartida, apresentam maior dificuldade de elaboração, formando grumos que implicam maior tempo de preparação dos tratamentos, além de dificultar a dosagem do meio nos frascos. A redução na germinação (comparada ao teste anterior) aparenta ter relação com a capacidade do meio em reter água e fornecê-la às sementes. Caldas et al. (1998) citaram que meios de cultura muito consistentes podem limitar a difusão de água e nutrientes para os explantes cultivados. Erig et al. (2004) testaram a utilização de amido de milho e amido de mandioca, em diversas combinações com água e ágar, como solidificantes alternativos na multiplicação in vitro de Malus domestica; os autores relataram que, do ponto de vista da multiplicação, a possibilidade de substituição do ágar é possível, especialmente por amido de milho. Segundo Caldas et al. (1998), observar o aspecto físico dos meios no decorrer do cultivo é muito importante, já que algumas plantas liberam a enzima amilase, capaz de degradar o amido e gerar perda de consistência, muitas vezes inviabilizando a continuidade dos experimentos de cultivo in vitro.

R. Árvore, Viçosa-MG, v.34, n.1, p.39-48, 2010

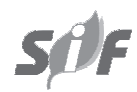


O aumento da germinação em meio líquido tendo como agente de sustentação a vermiculita sugere que a utilização de meios que forneçam mais água às sementes permitirão a embebição inicial necessária e, posteriormente, a ativação de metabólitos que auxiliarão a germinação. Meios líquidos podem não favorecer a respiração da semente sem a presença de um suporte; neste caso, a vermiculita serviu como suporte. Essas afirmativas estão de acordo com Caldas et al. (1998), que relataram que meios sólidos são mais eficientes no fornecimento de sais às plantas, enquanto meios líquidos reduzem a concentração de sais e aumentam o fornecimento hídrico. Outro fator relativo é a maior aeração do meio quando se utiliza vermiculita, igualmente relatado por Caldas et al. (1998), já que as sementes também necessitam de oxigênio para germinar. Porém, outros fatores podem ter inibido a germinação por exemplo da utilização de $\mathrm{NaOCl}$, o que se observou a posteriori. O substrato vermiculita favoreceu a germinação em Adenanthera pavonina quando comparado com o substrato papel-filtro (FANTI e PEREZ, 1999), resultado que corrobora o observado em sementes de Pinus taeda L.

Nos testes em que se utilizou germinação em algodão hidrófilo, foi observada boa germinação quando as sementes não passaram por desinfestação em etanol e $\mathrm{NaOCl}$, o que permite inferir sobre a toxidez apresentada por este último. Essa mesma toxicidade foi relatada por Zayat e Ranal (1997), reduzindo a germinação e aumentando o tempo para tal evento em sementes de Erechtites valerianaefolia. Além disso, algodão hidrófilo apresentou baixo índice de contaminação (a qual pode ser controlada com a desinfestação das plântulas), bem como a maior média de germinação observada, quando ocorreu embebição por $72 \mathrm{~h}$, pode ser considerada alta, especialmente quando comparada com os resultados já citados, observados em germinação sob papel-filtro, conforme relatados por Golle (2007).

O uso de tratamentos pré-germinativos de embebição melhorou as taxas de germinação in vitro de sementes de $P$. taeda, como anteriormente citado nos resultados. A embebição em água também acelerou, possivelmente, o processo de ativação metabólica das sementes, o que corrobora com a citação de Borges e Rena (1993) no que se refere as fases envolvidas na germinação. Franco e Ferreira (2002) observaram que a embebição de sementes de Didymopanax morototoni por $30 \mathrm{~min}$

R. Árvore, Viçosa-MG, v.34, n.1, p.39-48, 2010 em água e etanol resultaram em condições adequadas do tegumento para facilitar a germinação. Tratamentos pré-germinativos em Ormosia nitida melhoraram significativamente a absorção de água para germinação (LOPES et al., 2006). Já na germinação ex vitro de Caesalpinia pyramidalis, tratamentos pré-germinativos de embebição não foram tão satisfatórios quando comparados com outras técnicas de superação de dormência (ALVES et al., 2007).

\section{CONCLUSÕES}

Substratos alternativos conferem condições físicas adequadas para uso na cultura de tecidos, entretanto não favorecem a germinação in vitro de sementes de Pinus taeda.

A utilização de etanol $70 \%$ associado ao uso de NaOCl $3 \%$ por 5 min promove boa desinfestação das sementes, mas inibe a germinação in vitro de sementes de P. taeda.

A germinação em algodão hidrófilo sem tratamento de desinfestação permite a obtenção de plântulas que podem ser utilizadas para o cultivo in vitro, e esse substrato não favorece as contaminações, além de possuir baixo custo.

\section{AGRADECIMENTOS}

À empresa Klabin, pelas sementes; e à Capes, pela bolsa concedida.

\section{REFERÊNCIAS}

ASSOCIAÇÃO BRASILEIRA DA INDÚSTRIA DE MADEIRA PROCESSADA MECANICAMENTE ABIMCI. Madeira processada mecanicamente - estudo setorial. Curitiba: 2001. p.27.

ALVES, E. U. et al. Superação da dormência em sementes de Caesalpinia pyramidalis Tul.

Revista Árvore, v.31, n.3, p.405-415, 2007.

BACKES, P.; IRGANG, B. Árvores

cultivadas no sul do Brasil: guia de identificação e interesse paisagístico das principais espécies exóticas. Porto Alegre: Serafinense, 2004. 205p.

BORGES, E. E. L.; RENA, A. B. Germinação de sementes: In: AGUIAR, I. B.; PIÑA-RODRIGUES, F. C. M.; FIGLIOLIA, M. B. Sementes florestais tropicais. Brasília: Abrates, 1993. p.83-135. 
BURNS, A. B.; SCHWARZ, O. J.;

SCHLARBAUM, S. E. Multiple shoot production from seedling explants of slash pine (Pinus elliottii, Engelm.). Plant Cell Reports, v.10, n.9, p.439-443, 1991.

CALDAS, L. S.; PADMAJA, H.; FERREIRA, M. E. Meios nutritivos. In: TORRES, A. C.; CALDAS, L. S.; BUSO, J. A. Cultura de tecidos e transformação genética de plantas. Brasília: Embrapa-CNPH, 1998. p.87-132.

ERIG, A. C.; SCHUCH, M. W.; SILVA, L. C. Multiplicação in vitro de macieira (Malus domestica Borkh.) cv. Galaxy: meio de cultura e agentes solidificantes alternativos. Revista Brasileira de Agrociência, v.10, n.3, p.297-302, 2004.

FANTI, S. C.; PEREZ, S. C. J. G. A. Influência do substrato e do envelhecimento acelerado na germinação de olho-de-dragão (Adenanthera pavonina L. - Fabaceae). Revista

Brasileira de Sementes, v.21, n.2, p.135$141,1999$.

FERRARI, M. P. Beneficiamento e armazenamento de sementes de algumas espécies de Pinus. Colombo: Embrapa Floresta, 2003. 4p. (Documento, 69)

FRANCO, E. H.; FERREIRA, A. G. Tratamentos pré-germinativos em sementes de Didymopanax morototoni (Aubl.) Dcne. Et Planch. Ciência Florestal, v.12, n.1, p.1-10, 2002.

GEORGE, E. F.; SHERRINGTON. P. D. Plant propagation by tissue culture. Eversley: Exegetics, 1984. 593p.

GOLLE, D. P. Germinação in vitro de Pinus taeda L. a partir de sementes selecionadas. 2007. 94f. Dissertação (Mestrado em Engenharia Florestal) Universidade Federal de Santa Maria, Santa Maria, 2007.

GRATTAPAGLIA, D.; MACHADO, M. A. Micropropagação. In: TORRES, A. C.; CALDAS, L. S.; BUSO, J. A. Cultura de tecidos e transformação genética de plantas. Brasília: Embrapa-SPI/Embrapa/SNPH, 1998. p.183-260. v.1.
HARRY, I. S.; THORPE, T. A. Regeneration of plantlets through organogenesis from matures embryos of jack pine. Plant Cell, Tissue and Organ Culture, v. 37, n.2, p.159-164, 1994.

\section{INSTITUTO DE PESQUISAS E ESTUDOS} FLORESTAIS - IPEF. Ciência e tecnologia no setor florestal brasileiro: diagnóstico, prioridades e modelo de financiamento - Relatório final. Piracicaba: 2002. 12p.

LI, X. Y.; HUANG, F. H. Induction of somatic embryogenesis in loblolly pine (Pinus taeda L.) In Vitro Cellular \& Developmental Biology Plant, v.32, n.3, p.129-135, 1996.

LOPES, J. C.; DIAS, P. C.; MACEDO, C. M. P. Tratamentos para acelerar a germinação e reduzir a deteriorização das sementes de Osmosia nitida VOG. Revista Árvore, v. 30, n. 2, p. 171-177, 2006.

LORENZI, H. et al. Árvores exóticas no Brasil: madeireiras, ornamentais e aromáticas. São Paulo: Nova Odessa/Instituto Plantarum, 2003.368p.

McKELLAR, D. S.; HERMAN, B.; WATT, M. P. Towards a Protocol for the micropropagation of Pinus patula. South African Forestry Journal, v.171, p.33-41, 1994.

MURASHIGE, T.; SKOOG, F. A revised medium for rapid growth and bio assays with tobacco tissue cultures. Physiologia Plantarum, v. 15, n.3, p.473-497, 1962.

NOGUEIRA, C. N. et al. Germinação in vitro de murici-pequeno (Byrsonima intermedia A. Juss.). Ciência Agrotécnica, v.28, n.5, p. 1053 1059, 2004.

PARANJOTHY, K. et al. Clonal multiplication of woody perennials. In: BHOJWANI, S. S. Plant tissue culture: applications and limitations. Amsterdam: Elsevier, 1990. p.190-219.

PÉREZ-BERMÚDEZ, P.; SOMMER, H. E. Factors affecting adventitious bud induction in Pinus elliottii (Engelm.) embryos cultured in vitro. Plant Cell, Tissue and Organ Culture, v.11, n.1, p.25-35, 1987.

R. Árvore, Viçosa-MG, v.34, n.1, p.39-48, 2010 
PULLMAN, G. S.; NAMJOSHI, K.; ZHANG, Y. Somatic embryogenesis in loblolly pine (Pinus taeda L.) improving culture initiation with abscisic acid and silver nitrate. Plant Cell Reports, v.22, n.2, p.85-95, 2003.

SELLE, G. L.; SCHNEIDER, P. R.; FINGER, C.A. G. Classificação de sítio para Pinus taeda L. através da altura dominante, para a região de Cambará do Sul, RS, Brasil. Ciência Florestal, v.4, n.1, p.77-95, 1994.

SEN, S.; MAGALLANES-CEDENO, M. E.; KAMPS, R. H. In vitro micropropagation of Afghan pine. Canadian Journal of Forest Research, v.24, n.6, p.1248-52, 1994.

SERAFINI, L.A.; BARROS, N. M.; AZEVEDO, J. L. Biotecnologia: princípios e aplicações. In: SERAFINI, L. A.; BARROS, N. M.; AZEVEDO, J. L. Biotecnologia na agricultura e na agroindústria. Guaíba: Agropecuária, 2001.p.25-74.

STOJIEIÉ, D.; BUDIMIR, S.; CULAFIÉ, L. Micropropagation of Pinus heldreichii. Plant Cell, Tissue and Organ Culture, v.59, NUMERO, p.147-150, 1999.

STORCK, L. et al. Experimentação vegetal. 2 ed. Santa Maria: Universidade Federal de Santa Maria, 2006. 198p.
TEIXEIRA, J. B. Limitações ao processo de cultivo in vitro de espécies lenhosas. Brasília, DF: Embrapa - Cenargen. Disponível em: <http://www.redbio.org/.../simposios.pdf> Acesso em: 10 set., 2004.

TUOTO, M. Entrevista. 2 de abril de 2003. Disponível em: <http:// www.celuloseonline.com.br>. Acesso em: 12 jun., 2005.

WATAI, L. T. Substituição de espécies de madeira nativas por madeiras de reflorestamento. In: CONGRESSO FLORESTAL BRASILEIRO, 6., 1990, Campos do Jordão. Anais... São Paulo: SBS, SBEF, 1990. v.1. p.131-133.

WATANABE, K. N.; RAMAN, K. V. Plant biotechnology and plant genetic resources: a global perspective. In: WATANABE, K. N.; PEHU, E. Plant biotechnology and plant genetic resources for sustainability and productivity. Austin: Academic Press, 1997. p.1-13.

ZAYAT, A. G.; RANAL, M. A. Germinação de sementes de capiçova. Pesquisa Agropecuária Brasileira, v.32, n.11, p.12051213, 1997. 